\title{
An Acral lentiginous melanoma case with typical dermoscopy findings
}

\section{Tipik dermatoskopik bulguları olan Akral lentiginöz malign melanom vakası}

\author{
Hamza Aktaş ${ }^{1}$, Ahmet Şiyar Ekinci ${ }^{2}$, Onur Eşbah ${ }^{2}$ \\ ${ }^{1}$ Diyarbakır Gazi Yaşargil Eğitim Ve Araştırma Hastanesi, Dermatoloji Kliniği, Diyarbakır \\ ${ }^{2}$ Diyarbakır Gazi Yaşargil Eğitim Ve Araştırma Hastanesi, Tıbbi Onkoloji, Diyarbakır
}

Dergiye geliş tarihi:14/02/2015 Dergiye kabul tarihi:30/04/2015 Doi: 10.5505/aot.2016.33043

\section{ÖZET:}

Akral lentiginöz malign melanom (ALMM) nadir görülen ve kötü prognozlu bir malign melanom alt tipidir. Sıklıkla ileri evrede tanı alır. Karakteristik dermatoskopik bulguları olan bir ALMM vakası sunmaktayız.

Anahtar Kelimeler: Akral lentiginöz melanom, dermatoskopi, kötü prognoz

\begin{abstract}
:
Acral lentiginous malignant melanoma (ALMM) a rare subtype of malignant melanoma with poor prognosis. It is often diagnosed at advanced stage. We present a ALMM case with characteristic dermoscopy findings.

Keywords: Acral lentiginous melanoma, dermoscopy, dermatoscopy, poor prognosis
\end{abstract}

\section{Giriş-Amaç}

Malign melanom (MM); melanositlerden köken alan, deri ve mukozanın agresif tümörlerindendir (1). MM'nin insidansı diğer kanser türlerine göre giderek daha fazla artmaktadır (2). Bununla birlikte mortalite oranı yaşlılarda daha fazladır. $\mathrm{Bu}$ nedenle erken tanı ve tedavisi mortalite açısından önemlidir (3).

MM'de dermatoskopik incelemede üç özellik benign malign ayırımında önemlidir. Bunlar; asimetri, atipik pigment ağı ve mavi-beyaz yapılardır. $\mathrm{Bu}$ kriterlerden 2 veya 3 tanesi pozitif olursa lezyonun çıkarılması ve histopatolojik inceleme yapılması önerilir. Bununla birlikte patern analizi, ABCDE kural1, Menzies metodu, yedi özellik kontrol listesi gibi birçok değerlendirme algoritması da bulunmaktadır (1).

Anatomik lokalizasyona, tümörün büyüme ve histopatolojik tipine göre dört ana tip tanımlanmıştır. En sık yüzeyel yayılan tip görülürken daha sonra sirasiyla, nodüler, lentigo ve akral lentiginöz malign melanom (ALMM) görülür $(1,2)$. ALM MM'nin 4 ana tipinden biridir. Oldukça nadir görülen bir tiptir ve çoğunlukla 60-70 yaşlarında görülür. Tüm MM'ler içerisinde ortalama \%2-3 oranında görülür ve etnik gruplar arasında görülme sıklığ 1 birbirine benzerdir $(2,3)$. Biz bu raporda 79 yaşında, lenf nodu tutulumu olan, geç tanı almış karakteristik dermatoskopik bulguları olan bir hasta sunmaktayiz.

\section{Olgu}

Yetmiş dokuz yaşında erkek hastada, yaklaşık olarak yedi ay önce sol ayak plantar yüzde 1-2 $\mathrm{mm}$ boyutunda koyu renkli bir lezyon ortaya çıkmıştı. Lezyon total eksize edilmiş, ancak histopatolojik inceleme yapılmamıştı. Üç ay sonra aynı bölgede lezyon nüks etmişti. Bu şikayet ile polikliniğimize başvuran hastanın yapılan dermatolojik muayenesinde, sol ayak plantar yüzde $12 \times 10 \mathrm{~cm}$ boyutlarında, medial bölge ve arkus bölgesinde maküler zemin üzerinde yer yer ülsere mavi-siyah nodüller mevcuttu (Resim 1). Lezyonun dermatoskopik özellikleri incelendiğinde; atipik pigment ağı, mavi-beyaz alanlar, irregüler nokta ve globüller, atipik vasküler ve hemorajik alanlar olmak üzere MM'nin birçok dermatoskopik özelliği tespit edildi (Resim 2-4). Hastada displastik veya kongenital nevüs öyküsü yoktu, hastanın ifadesinde soy geçmişinde herhangi bir özellik yoktu.

Lezyon histopatolojik inceleme amaciyla total eksize edildi ve kalınlığ $1.5 \mathrm{~cm}$, Clark evre V 
MM olarak raporlandı. İğsi hücrelerin olduğu, ancak lenfositik infiltrasyonun olmadığ1 tespit edildi. Satellit nodülün olmadığı saptandı. Mitotik hızı 6/10 büyük büyütme alanı olarak tespit edildi, lenfatik/vasküler boşluk invazyonu vardı. Tümör yan cerrahi sinırlarda negatif, ancak taban cerrahi sinırında mevcuttu. İmmünohistokimyasal olarak tümör hücreleri Melan A, ve S-100 ile negatif iken, ancak sadece HMB-45 ile pozitif saptand1.

Sağ inguinal bölgeden en büyüğü $3.5 \mathrm{~cm}$ uzun eksene sahip 18 adet lenf nodu diseke edildi, yapılan histopatolojik incelemede 12 nodülde

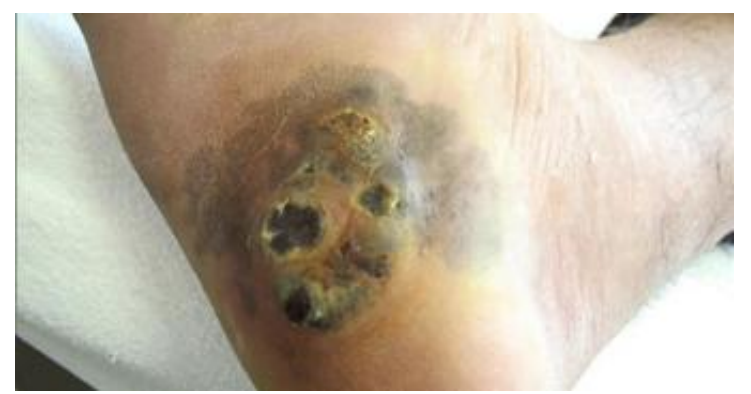

Resim 1: Maküler zeminde ülsere, nodüler lezyon.

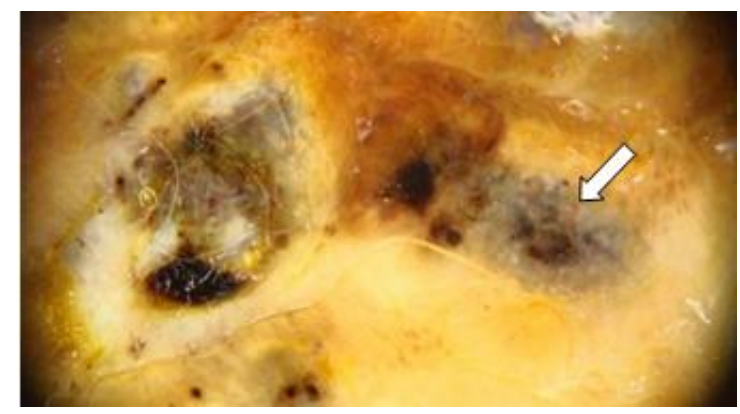

Resim 2: Mavi-beyaz peçe görünümü.

\section{Tartışma}

ALMM ilk olarak 1976 yılında Reed tarafindan tanımlanmıştır (3). Tipik olarak renk varyasyonları gösteren, düzensiz kenarl1, asimetrik, kahverengiden siyaha değişebilen renkte bir makül olarak kendini gösterir. $\mathrm{Bu}$ melanom tipi palmoplantar ve subungual bölgeye yerleşir. Radial veya 'lentiginöz' büyüme fazı vardır. Lezyon $3 \mathrm{~cm}$ 'nin üzerine çıktığında nodüler formasyon oluşmaya başlar. Özellikle başparmakta olmak üzere subungual yerleşim yaygın görülür. Tirnakta kahverengi veya siyah bant görünümü, tırnak distrofisi ve Hutchinson bulgusu sik görülen klinik bulgularıdır. ALMM kutanöz melanomun nadir görülen bir tipidir. İleri evrede tanı aldığ1 için kötü bir prognoza sahiptir $(1,3)$.
MM metastazı tespit edildi. Hemogram, biyokimyasal tetkikler, eritrosit sedimantasyon hizl ve c-reaktif protein normal saptand. Görüntüleme tetkiklerinde metastaz saptanmadi. Amerikan Kanser Komitesi Birliğinin belirlemiş olduğu kriterlere göre tümörün TNM evresi IIIC (T2N3M0) olarak tespit edildi. Hastanın ileri yaşı ve yan etki profili göz önüne alınarak hastanın da kabul etmemesi nedeniyle adjuvan tedavi uygulanmadi. Hastanın 6 ay sonraki izleminde herhangi bir patolojiye rastlanmadı. Hastanın takibi devam etmektedir.

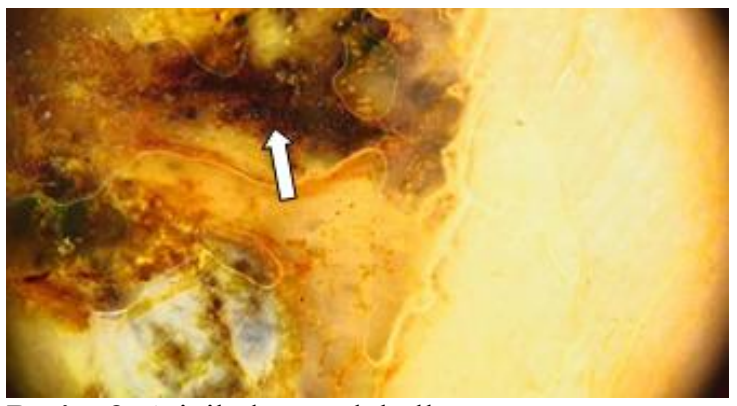

Resim 3: Atipik dot ve globüller

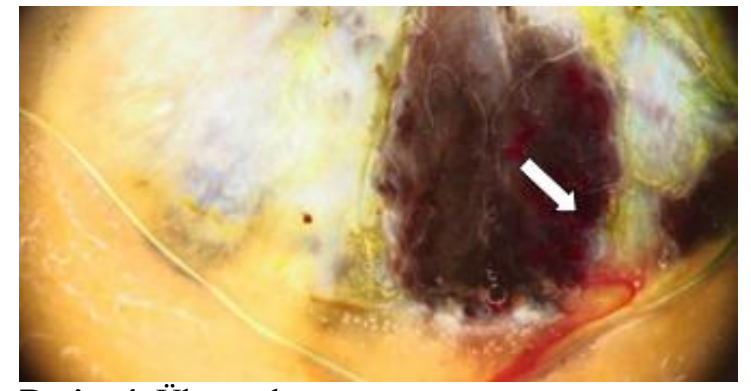

Resim 4: Ülsere alan.

Pigmentli deri lezyonlarının tanısında, ayırıcı tanısında ve izlemlerinde oldukça önemli bir yöntem olan dermatoskopi, klinik tanı ile histopatolojik değerlendirme arasında önemli veriler sağlayan bir yöntem olarak önem kazanmıştır (4). İnvaziv olmayışı, pratik ve çabuk sonuç vermesi, hem hasta hem de doktor açısından zararsız olması son yıllarda kullanım alanlarının artmasını sağlamıştır (5).

Dermatoskopinin en önemli rolü özellikle erken dönemdeki malign melanomu benign pigmente lezyonlardan ayırt edebilmesidir. Klinik olarak melanom düşünülmeyen olgularda iyi bir dermatoskopik değerlendirme ile melanoma özgü değişikliklerin gösterilmesi ve erken tedavi olanağı doğmaktadır. $\mathrm{Bu}$ da melanom ile melanositik nevus ayrımını sağlamakta, melanomda tanı doğruluğunu \%90'lara kadar Adress for correspondence: Uzm dr Ahmet Şiyar Ekinci. Diyarbakır Gazi Yaşargil Eğitim Ve Araştırma Hastanesi Üç kuyular kayapınar 21070 Diyarbakır - Türkiye e-mail: a.siyar@hotmail.com

Available at www.actaoncologicaturcica.con

Copyright $\odot$ Ankara Onkoloji Hastanesi 
çıkarmakta ve 5 yıllık yaşam şansını arttırmaktadır (4).

ALMM'de tipik dermatoskopik görüntü paralel surt paternidir. Bununla birlikte multi komponent patern, irregüler diffüz pigmentasyon, atipik pigment ağ1 akral melanomda görülen diğer dermatoskopik bulgulardır(1). Histopatolojik incelemede; dermo-epidermal bileşkede melanosit proliferasyonu, atipik melanositler, irregüler epidermal hiperplazi ve invaziv evrede dermiste iğsi hücrelerin varlığ $\tan 1$ koydurucudur (1).

MM şüphesi taşıyan bir lezyonda ideal tedavi 1-3 mm cerrahi sinırla lezyonun total eksizyonudur. Histolojik tanıy takiben Breslow kalınlığına göre belirlenen uygun cerrahi sinırla yeniden eksizyon uygulanmalıdır. İn-situ lezyon için cerrahi sınır 0.5-1 cm iken, $1 \mathrm{~mm}$ 'nin altındaki bir lezyon için $1 \mathrm{~cm}, 1-2 \mathrm{~mm}$ 'lik bir lezyon için 1-2 cm, 2-4 mm'lik lezyon için $2 \mathrm{~cm}$ olmalıdır. Yapılan çalışmalarda $2 \mathrm{~cm}$ 'nin üzerinde sağlam deriyi almanın lokal rekürrens oranını azaltmadığı bildirilmiștir $(6,7)$.

Gerekirse yüzeyel fasyayı içine alacak şekilde bütün lenfatik kanallar cerrahi olarak çıkarılabilir. Derin fasyada tümör invazyonu yoksa çıkarılmasının yaşam süresi ya da nüks üzerine etkisi yoktur. Genellikle yara primer olarak kapatılır. Geniş doku kaybı varsa greft veya flep ile yara kapatılır $(7,8,9)$.

Bölgesel lenf nodu tutulumu kötü prognoz işaretidir. Tedavi amacıyla yapılan lenf nodu diseksiyonu yüzeyel lenf nodlarını, klinik gereklilik halinde inguinal lenf nodlarını içermelidir(10). Sonuç olarak; ALMM, tanısı geç konulan ve prognozu kötü bir MM tipidir.
Erken tanı ve doğru yaklaşımlar tedavi şansını artırabilir.

\section{Çıkar çatışması: Yok}

\section{Kaynaklar}

1. Situm M, Buljan M, Kolic M, Vucic M. MelanomaClinical, Dermatoscopical, and Histopathological Morphological Characteristics. Acta Dermatovenerologica Croatica 2014;22(1):1-12

2. Rigel DS, Carucci JA. Malignant melanoma: prevention, early detection, and treatment in the 21 st century. CA Cancer Journal for Clinicians. 2000; 50: 215-236

3. Reed R. Acral lentiginous melanoma. in New Concepts in Surgical Pathology of the Skin,W. Hartmann and R. Reed, Eds. JohnWiley \& Sons, New York, NY, USA, 1976; 89-90

4. Güneş AT, Avcı O, Özkan Ş. Dermatoskopi. II: Dermatolojide Gelişmeler Sempozyumu. Sempozyum kitabı, Ankara 1993;192-200.

5. MacKie RM. An aid to the preoperative assessment of pigmented lesions of the skin. Br J Dermatol 1971;85(3):232-8

6. Hudson DA, Krige J EJ, Stubbings H. Plantar melanoma: results of treatment in three population groups. Surgery. 1998; 124: 877-882

7. National Comprehensive Cancer Network Practice Guidelines in Oncology. http://www.nccn.org

8. Balch CM, Soong SJ, Smith T. et al. Long-term results of a prospective surgical trial comparing 2 $\mathrm{cm}$ vs. $4 \mathrm{~cm}$ excision margins for 740 patients with 1-4mm melanomas. Annals of Surgical Oncology. 2001; 8(2): 101-108

9. Hansen S, Mathes S, Young D. Skin and subcutaneous tissue. in Schwartz's Principles of Surgery, Brunicardi FC, Andersen DK, Billiar TR, Dunn DL, Hunter JG, and Pollock RE, Eds., pp., McGraw-Hill, New York, NY, USA, 8th edition, 2005;1297-1315

10. Hughes TMD, A'Hern RP, Thomas JM. Prognosis and surgical management of patients with palpable inguinal lymph node metastases from melanoma. British Journal of Surgery. 2000; 87: 892-901. 